\title{
ANIME JEPANG SEBAGAI SUMBER PEMBELAJARAN PKN
}

\author{
Wisnu Hatami
}

\author{
IAIN Syekh Nurjati Cirebon \\ wihatami17@gmail.com
}

\begin{abstract}
ABSTRAK
Penelitian ini bertujuan untuk memperkaya sumber pembelajaran pada Pendidikan Kewarganegaraan (PKn) di sekolah.Mata pelajaran PKn masih dianggap sebagai mata pelajaran yang monoton dan hanya mengedepankan pengetahuan kognitif, materi yang jauh dari kehidupan sehari-hari siswa, dan sumber pembelajaran yang terbatas. Oleh karena itu, guru PKn dituntut untuk mampu menjawab tantangan masa kini dengan memanfaatkan media digital sebagai sumber dalam pembelajaran PKn. Media pembelajaran yang bisa digunakan sebagai sumber pembelajaran adalah anime Jepang. Anime merupakan animasi atau tayangan kartun yang identik dengan Negara Jepang. Dalam anime Jepang biasanya terdapat nilai-nilai karakter yang dapat dianalisis maupun dipelajari oleh para peserta didik sehingga tidak menimbulkan kesan monoton dalam proses pembelajaran. Hasil penelitian menunjukkan beberapa hal, pertama, anime Jepang sudah dikenal oleh peserta didik sejak usia dini sehingga memudahkan peserta didik dalam mengenal karakter dalam anime. Kedua, terdapat berbagai nilai karakter dalam anime Jepang. Terdapat kekhasan nilai karakter seperti kerja keras, disiplin, rajin, rendah hati dan sebagainya yang selalu terdapat dalam anime Jepang. Nilai-nilai karakter dalam anime Jepang relevan dengan pembelajaran PKn sehingga dapat menjadi alternatif sumber pembelajaran bagi mata pelajaran Pendidikan Kewarganegaraan.
\end{abstract}

\section{Kata Kunci: Anime; Sumber Belajar; Pendidikan Kewarganegaraan}

\section{ABSTRACT}

This research aims to enrich learning resources in Citizenship Education (PKn) in schools. PKn subjects are still considered monotonous subjects and only promote cognitive knowledge, materials away from students' daily lives, and limited learning resources. Therefore, $P K n$ teachers are required to be able to answer today's challenges by utilizing digital media as a resource in learning PKn. Learning media that can be used as a learning source is Japanese anime. Anime is an animation or cartoon show that is identical to the State of Japan. In Japanese anime there are usually character values that can be analyzed or studied by the learners so as not to cause a monotonous impression in the learning process. The results showed several things, first, Japanese anime has been known by learners from an early age, making it easier for learners to get to know the characters in the anime. Second, there are various character values in Japanese anime. There are unique character values such as hard work, discipline, diligent, humble and so on that are always present in Japanese anime. Character values in Japanese anime are relevant to PKn learning so that it can be an alternative learning resource for Civic Education subjects.

Keywords: Anime; Learning Resources; Citizenship Education

Jurnal Edueksos Vol IX, No. 2, Desember 2020

The journal of social and economics education 


\section{A. PENDAHULUAN}

Pembelajaran Pendidikan Kewarganegaraan ( $\mathrm{PKn}$ ) masih dianggap sebagai mata pelajaran yang membosankan. Stigma bahwa PKn merupakan mata pelajaran hafalan harus terus dikikis. Penulis melihat bahwa terdapat beberapa persoalan yang terdapat dalam pembelajaran PKn secara umum. Pertama, PKn dianggap sebagai mata pelajaran yang mengedepankan pengetahuan kognitif semata. Kedua, materi pembelajaran yang terkesan berat dan jauh dengan kehidupan sehari-hari siswa. Ketiga, media pembelajaran yang digunakan guru terbatas. Keempat, evaluasi pembelajaran yang dilakukan guru masih sebatas menilai pengetahuan siswa. Kelima, sumber pembelajaran belum mengeksplorasi yang dekat dengan kegiatan sehari-hari siswa. Belum maksimalnya pelajaran PKn tentu akan berdampak pada belum maksimalnya pendidikan karakter yang selama ini kita cita-citakan. PKn menitikberatkan pada pembelajaran nilai karakter. Maka dari itu sudah sepatutnya guru PKn menjawab tantangan menanamkan nilai karakter pada peserta didik di era globalisasi ini.

Berbagai upaya perlu terus dilakukan seperti metode pembelajaran project citizen maupun metode pembelajaran lain. Salah satu upaya dalam meningkatkan proses belajar mengajar mata pelajaran PKn adalah dengan menggunakan media pembelajaran digital sebagai sumber belajar. Media pembelajaran digital merupakan suatu keniscayaan dalam pembelajaran sebab melihat majunya perkembangan dunia digital dan dekatnya siswa dengan kehidupan digital dapat memudahkan proses pembelajaran PKn dengan kegemaran siswa. Oleh karena itu, seorang pendidik dituntut agar dapat memanfaatkan media digital sebagai salah satu sumber pembelajaran. Alternatif media yang bisa digunakan untuk menjadi sumber pembelajaran adalah anime Jepang.

Ada beberapa alasan mengapa anime Jepang dapat menjadi sumber pembelajaran dalam mata pelajaran PKn. Pertama, anime bersifat general dan hampir semua peserta didik mengetahui anime. Kedua, karakter-karakter dalam anime memiliki nilai-nilai yang kuat dan dapat dijadikan bahan pembelajaran. Ketiga, alur 
cerita dalam serial anime relatif sederhana dan dekat dengan aktivitas sehari-hari. Keempat, anime menjadi kekuatan bagi Jepang. Seperti diungkap Allison dalam Macwilliams (2008 hlm. 5) mengatakan "kepopuleran manga dan anime di seluruh dunia juga dianggap sebagai bukti kekuatan ekspresif (expressive strength) yang dimiliki oleh seniman Jepang". Karena ketenaran anime dan manga tersebutlah Pemerintahan Jepang sendiri mendorong agar hal ini menjadi alat ekspor budaya Jepang ke negara lain. Kelima, dengan memanfaatkan kemajuan internet, anime dapat menjadi penghubung tranfer nillai yang ingin disampaikan. Feriansyah (2015 hlm 18) berpendapat "kemajuan TIK telah menghadirkan peluang dan keuntungan bagi kehidupan warganegara khususnya dalam praktik kewarganegaraan. Untuk mengoptimalkan kemajuan TIK bagi kehidupan warganegara, maka warganegara harus memiliki karakteristik dan kompetensi di era digital.

Era digital erat kaitannya dengan studi media. Menurut Hanif (2011) Akar studi media dapat dilacak dari keingintahuan hubungan antara media dan kebudayaan. Studi media dimulai pada tahun 1920-an sebagai respon terhadap munculnyaberbagai media massa seperti jaringan radio, sirkulasi surat kabar dan majalah, dan televisi tahun 1930an. Studi awal tentang media dipengaruhi oleh obsesi eropa yang mengklaimmemiliki kultur yang tinggi. Media bertugas untuk merepresentasikan kultur yang tinggitersebut dan mengabaikan kebudayaan di luar eropa dan koloni kekuasaan eropa. Periode iniditandaidengan menyebar luasnya hegemoni produksi dan sirkulasi media Inggris yaitu BBCdan Routers.

Media baru (era digital) adalah istilah yang digunakan dalam kemunculan digital, jaringan internet khususnya teknologi informasi komputer. Media baru sering di gunakan untuk menggambarkan teknologi digital. Dalam pembelajaran PKn, selalu berkaitan dengan pendidikan karakter. Saat ini pendidikan karakter sangat dibutuhkan untuk peserta didik. Maka dari itu, pembelajaran PKn harus mampu menjawab tantangan bagaimana membelajarkan nilai-nilai karakter bangsa kepada para peserta didik.Sumber pembelajaran menjadi hal yang sangat penting guna melatih siswa untuk lebih mampu untuk menganalisis hal yang berkaitan dengan nilai-nilai 
karakter. Didasari oleh apa yang telah dikemukakan sebelumnya maka penulis tertarik melakukan kajian “Anime Jepang sebagai Sumber Pembelajaran PKn”.

\section{Kajian tentang anime}

Jepang memiliki kebudayaan popular yang sangat kreatif seperti manga, anime, cosplay, hingga J-Pop. Banyak peneliti telah melakukan penelitian yang berkaitan dengan budaya popular Jepang seperti Condry (2011) yang membahas melalui analisis etnografi dan Wing-Fai (2014) yang membahas Selebriti dalam media budaya Jepang, serta Venus dan Helmi (2010) tentang Budaya Populer Jepang di Indonesia: Catatan Studi Fenomenologis Tentang Konsep Diri Anggota Cosplay Party Bandung.

Budaya pop Jepang khususnya anime sangat menarik perhatian di berbagai kalangan penjuru dunia. Craig (2000) menyimpulkan banyak faktor yang menjadikan manga dan anime Jepang mendapatkan penerimaan dengan baik hingga ke luar Jepang yaitu: pertama, "budaya pop Jepang berkualitas tinggi dan memiliki seni kreativitas". Kreativitas dari segi cerita yang tidak terduga maupun kreativitas dari segi penggambaran karakter peran yang dimainkan sangat baik. Begitu pula dengan kualitas dalam pembuatan produk animasinya. Anime Jepang menarik untuk ditonton karena memiliki karakter yang kuat dalam setiap detail animasi.

Kedua, "budaya populer Jepang mengandung unsur kehidupan, mimpi, dan relevansinya. Budaya populer Jepang mencakup kehidupan dengan semua dimensinya. Tema yang diangkat ke dalam manga dan anime sangat berkaitan dengan aktivitas manusia pada umumnya meliputi kasih sayang, hal baik dan hal buruk, hubungan antara manusia dan alam, serta mimpi untuk masa depan”. Hal ini juga yang membuat cerita dalam anime merupakan cerita yang tidak asing dan membuatnya menjadi lebih mudah dipelajari dalam pembelajaran PKn. Ketiga, "budaya populer Jepang memiliki aspek hubungan di antara manusia, pekerjaan dan perkembangan spiritualitas. Dalam manga dan anime, kompleksitas hubungan antar tokoh merupakan hal yang penting, seperti hubungan dengan keluarga (ayah, ibu, anak, saudara), hubungan dengan teman sekelas maupun teman kerja, hubungan dengan kekasih, hingga hubungan dengan orang yang dibenci.Selain hubungan antar 
tokoh, pekerjaan yang dilakukan tokoh tersebut juga merupakan hal yang digambarkan dengan jelas dalam manga dan anime".Aspek hubungan antar manusia ini pula yang dapat dikaji dan dapat menjadi sumber pembelajaran bagi pelajaran PKn.

Perkembangan budaya populer Jepang terutama anime tidak hanya mempengaruhi kehidupan sehari-hari warga Jepang, tetapi juga memberi pengaruh yang signifikan pada masyarakat yang menyukai anime di negara lain. Pengaruh ini dapat dilihat antara lain dari anime yang banyak ditonton oleh penggemarnya dan menjadi suatu kebutuhan bagi mereka untuk selalu mengikuti perkembangan anime yang sedang tayang. Pengaruh anime ini juga dapat dilihat dari banyaknya literatur yang ditulis mengenai perkembangananime yang tidak hanya ditulis oleh penulis Jepang, namun juga oleh penulis asing. Anime juga sering menjadi bahan diskusi para akademisi sebagai budaya populer Jepang yang sangat diminati.

Cara memanfaatkan budaya oleh Jepang dilakukan dengan menggunakan industri yang terlihat sangat sederhana namun bermakna untuk memperkenalkan budaya yang mereka miliki, yaitu film animasi atau anime. Anak-anak di Jepang sejak tahun 1960-an sudah mengenal anime sebagai hiburan mereka dan saat ini diperkenalkan ke seluruh dunia. Beberapa anime muncul sebagai favorit anak-anak seperti Doraemon, Conan, Astro Boy, Dragonball. Selain itu, film Spririted Away pun mampu memenangkan piala Oscar kategori film kartun terbaik 2003. (Kedutaan Besar Jepang dalam Affandi dkk (2015).

Dengan segala kemajuan yang dimilikinya, Jepang merupakan negara yang patut dijadikan contoh positif. Terlebih, kesesuaian antara adat ketimuran memberikan kesan bahwa dibanding mencontoh negara-negara Eropa maupun Amerika, mencontoh Jepang menjadi suatu keniscayaan. Seperti diungkapkan oleh Affandi dkk (2015 hlm 3) bangsa Indonesia sangat tepat belajar dari Jepang soal kinerja dan pengelolaan kehidupan dan sumber daya yang efisien. Bagi bangsa Indonesia, belajar dari Jepang bukanlah hal yang baru. Menurutnya, berkat Indonesia belajar dari Jepang maka Indonesia mampu keluar dari belenggu Belanda. Meskipun 
memang penjajahan Jepang juga musibah namun melihat sisi positifnya kita juga dapat menyebutnya sebagai anugrah. Dari pendapat tersebut dapat dilihat bahwa Indonesia mencontoh Jepang bukanlah hal yang baru.Indonesia dapat merdeka pun sedikit banyaknya karena Indonesia belajar dari bangsa Jepang ketika menjajah.

\section{Kajian tentang Pendidikan Kewarganegaraan}

Upaya untuk menjadikan warga negara yang demokratis dan bertanggung jawab sebenarnya sudah lama dan banyak dilakukan, terutama di dunia persekolahan dengan ujung tombaknya melalui Pendidikan Kewarganegaraan. (Rohani, 2015 ; Wijaya, 2020). Pendidikan Kewarganegaraan merupakan salah satu bidang kajian dalam konteks pendidikan nasional yang memiliki peran strategis bagai pembentukan karakter bangsa (nation and character building). ada tiga domain PKn yaitu domain kurikuler, domain sosio kultural, dan domain kajian ilmiah, ketiga domain itu memiliki keterkaitan antara satu dan lainnya. Dari ketiga domain yang disebutkan, terdapat keterkaitan antara yang satu dengan yang lain. Pendidikan tentu akan bermuara pada terbentuknya warga negara yang memiliki kepribadian yang baik. Dengan pendidikan akan menjadikan warga negara memiliki kedewasaan pola pikir dan juga kedewasaan perilaku. Maka dari itu pendidikan merupakan sarana tumbuh dan berkembangnya manusia yang kreatif, mandiri, bertanggung jawab. (Winataputra dan Budimansyah, 2012).

Dalam lingkup pendidikan kewarganegaraan di Indonesia, Mansoer dalam Erwin (2010, hlm 2) mengungkapkan Pada hakikatnya Pendidikan Kewarganegaraan itu merupakan hasil dari sintesis antara civic education, democracy education, serta citizenship yang berlandaskan Filsafat Pancasila dan juga mengkaji identitas nasional Indonesia serta memuat tentang bela Negara. Rahmat dkk (2013, hlm 8) mengatakan "Pendidikan Kewarganegaraan di Indonesia seperti yang berkembang di Negara lain memiliki multidimensional, artinya bahwa program PKn bukan hanya untuk satu tujuan".

Dari dua pendapat ini dapat dilihat bahwa Pendidikan Kewarganegaraan bertujuan untuk mempersiapkan warga negara muda agar ke depannya menjadi warga 
negara yang siap dan matang serta memiliki kesetiaan tinggi terhadap bangsa dan negaranya dan juga memiliki rasa nasionalisme. Winataputra dan Budimansyah (2012 hlm 15), Esensi pendidikan kewarganegaraan adalah membantu para siswa dalam mengembangkan kompetensi warga negara, juga dapat membantu para siswa dalam mengambil keputusan yang baik dan lurus sebagai warga negara yang global juga berbhineka.

\section{Landasan Teori fenomenologi}

Bagi Schutz dalam Kuswarno (2009 hlm 110), tugas utama analisis fenomenologi adalah merekontruksi dunia kehidupan manusia sebenarnya dalam bentuk yang mereka sendiri alami. Realitas yang terdapat pada dunia tersebut memiliki sifat intersubjektif yang berarti bahwa anggota di dalam masyarakat saling berbagi persepsi dasar mengenai dunia yang mereka internalisasikan lewat sosialisasi dan selanjutnya dapat mereka kembangkan dalam interaksi atau komunikasi. Dalam konteks fenomenologis, warganegara muda yang menyukai budaya populer anime adalah aktor yang melakukan tindakan sosial dan secara sengaja menampilkan diri sebagai penggemar budaya populer Jepang.

\section{Konsep Media Exposure}

Media Exposure menurut Rakhmat (2009 hlm 14) diartikan sebagai terpaan media, media exposure dapat dioperasionalkansebagai frekuensi individu dalam menyaksikan televisi, film, membaca majalah atau surat kabarmaupun mendengarkan radio.

\section{Teori interaksi Simbolik}

Blumer dalam Kuswarno (2009), mengungkap tiga premis yang mendasari pemikiran interaksionisme simbolik, yaitu: Bertindaknya manusia terhadap sesuatu didasarkan pada pemaknaan bagi mereka tentang makna-makna tersebut. Interaksi sosial dengan orang lain menciptakan makna tersebut. Saat interaksi sosial berlangsung membuat makna-makna tersebut menjadi sempurna.

\section{B. METODE PENELITIAN}

Pendekatan ini menggunakan pendekatan kualitatif disertai metode deskriptif. 
Metode deskriptif dianggap tepat digunakan dalam penelitian ini. Alasan penggunaan metode ini yaitu pertama, metode deskriptif tidak terbatas hanya sampai pengumpulan data, tetapi meliputi analisis data dan menginterpretasikan tentang arti data tersebut. Dengan menggunakan metode deskriptif, pembahasan masalah dan analisis data menjadi efektif dan lebih mudah dipahami. Kedua, metode ini memudahkan dalam menyusun data dari hasil wawancara pendapat ahli dan observasi yang akan ditarik kesimpulan yang baik. Oleh karena itu penelitian ini akan cocok dengan menggunakan metode deskriptif. Penelitian ini dibantu oleh Association of Highschool Nihon No Kurabu atau Soshonbu Bandung sebagai partisipan. Soshonbu adalah komunitas pecinta Jepang dari ekstrakulikuler Japanese Club sekolah yang ada di Bandung. Selain itu, Dianni Risda, M.Ed juga menjadi ahli dalam bahasa dan budaya Jepang.

\section{HASIL DAN PEMBAHASAN}

Pada bagian ini akan disajikan temuan dan pembahasan penelitian. Temuan penelitian ini berupa ringkasan hasil wawancara dengan subjek penelitian yang dilakukan kepada 13 warganegara muda Kota Bandung dan 1orang pakar budaya Jepang.Berdasarkan hasil wawancara dengan subjek penelitian, ditemukan bahwa warganegara muda khususnya di Kota Bandung memiliki minat yang tinggi terhadap budaya populer Jepang. Hal ini terlihat dari banyaknya festival-festival yang berkaitan dengan budaya populer Jepang yang dilaksanakan di Kota Bandung dan selalu ramai peminatnya.Ini memperlihatkan bahwa warganegara muda Kota Bandung memang memiliki penggemar budaya populer Jepang yang tidak sedikit. Hal ini senada dengan hasil wawancara dengan pakar budaya Jepang, Dianni Risda yang mengatakan: Saya rasa di Bandung ini antusiasmenya sangat tinggi.Mungkin karena lingkungan Bandung pun sangat mendukung untuk berkembangnya pop culture Jepang.Dari budaya makan sendiri sangat mudah ditemukan restoran-restoran yang bernuansa Jepang.Ini membuktikan bahwa memang peminat dari budaya Jepang di Bandung memang ada segmentasinya tersendiri.

Selanjutnya, temuan penelitian menunjukkan bahwa subjek penelitian telah 
menyukai budaya populer anime Jepang relatif lama. Hal ini terlihat dari pernyataan subjek penelitian tentang sejak kapan menyukai anime Jepang dan darimana mengetahui anime. Bahwa judul-judul yang sangat familiar seperti Naruto, Doraemon, Dragonball merupakan anime yang sangat diminati oleh semua kalangan. Bukan hanya anak kecil namun remaja bahkan dewasa pun masih memiliki minat terhadap judul ini karena ceritanya yang tidak asing dengan kegiatan sehari-hari seehingga nyaman untuk ditonton sebagai hiburan. Selain itu, dapat dilihat bahwa produk anime Jepang saat ini semakin banyak sehingga dengan banyaknya pilihan menjadi tidak cepat bosan dalam mengikuti perkembangan anime. Dianni Risda mengatakan bahwa "kalau sekarang banyak sekali judul animenya. Saya sendiri sudah susah mengikuti perkembangannya. Tapi di indonesia pasti orang tidak akan ada yang tidak tahu tentang doraemon, nobita, shinchan, naruto. Juga anime-anime lain yang warganegara muda pasti lebih tahu perkembangannya". Selanjutnya, temuan penelitian menunjukkan bahwa warganegara muda Indonesia mendapatkan anime Jepang dengan memanfaatkan perkembangan era digital yaitu dengan mengunduh file yang biasanya tersedia web online maupun sharing dengan teman yang lebih dulu mengunduhnya. Tidak jarang pula warganegara muda Indonesia memanfaatkan fitur streaming yang biasanya disediakan dalam forum-forum yang membahas tentang budaya populer Jepang.

\section{Nilai karakter dalam anime}

Fungsi pendidikan budaya dan karakter bangsa adalah: (1) Pengembangan: pendidikan berfungsi untuk menjadikan peserta didik berperilaku baik dan memiliki sikap berkarakter bangsa; (2) Perbaikan: potensi peserta didik menjadi lebih bertanggungjawab dan bermartabat; (3) Penyaring: berfungsi sebagai penyaring ketika ada ketidaksesuaian nilai budaya dan karakter bangsa yang baik (Garcia, 1982; May, 2001; Rawls, 2006; dan Zuriah \& Sunaryo, 2009) dalam Zuriah (2014).

Anime memiliki ciri khas yaitu ada nilai karakter yang diangkat dan dijadikan sebagai pesan moral yang terkandung di dalamnya. Seperti diutarakan oleh Dianni Risda yang mengatakan: "biasanya anime Jepang itu memiliki ciri khas tersendiri. 
Nilainya itu bukan bersifat doktrin tapi lebih kepada nilai yang berada pada kehidupan keseharian. Jadi penonton pun secara tidak sadar menyadari dalam anime itu ada nilai. Walaupun tidak ditampilkan secara dominan dalam cerita.Misalnya saja anime tentang olahraga.Itu biasanya menunjukkan nilai perjuangan, kerja keras, disiplin, berjuang untuk meraih mimpi.Itu dikemas dengan khas Jepang sehingga enak untuk diikuti”.

Selanjutnya, cerita yang dekat dengan kehidupan sehari-hari merupakan kekuatan dalam anime Jepang.Berdasarkan data penelitian, bahwa yang membuat budaya populer Jepang khususnya anime menarik adalah anime memiliki kekuatan di dalam ceritanya. Cerita dalam anime biasanya cerita yang dekat dengan kehidupan sehari-hari.Selain itu, anime dianggap mampu untuk masuk ke dalam semua kalangan baik itu anak-anak, remaja, bahkan dewasa karena memang memiliki genre yang sangat banyak. Dibanding animasi lain, anime memiliki kekuatan tersendiri.

Hal itu tergambar dari pernyataan subjek penelitian yang mengatakan bahwa anime Jepang memiliki cerita yang berkelanjutan setiap minggunya dan memiliki cerita yang lebih menarik dibanding animasi lain. Cerita dalam anime Jepang unik dan berbeda, melibatkan emosi sehingga yang melihatnya seperti terbawa ke dalam cerita tersebut. Selain itu, artwork dari anime Jepang melibatkan detail yang lebih tajam sehingga tidak nampak asal jadi serta pengisi suara dalam anime mampu menyeimbangkan dengan grafis yang memang sangat bagus.Selain dari segi cerita, ditambah lagi dengan grafis dan art work yang sangat baik sehingga ketika sedang menontonnya, penonton dimanjakan dengan tampilan yang sangat bagus dan nyaman.

Segi visual dan artwork pun memiliki andil dalam faktor yang menyebabkan warganegara muda menyukai anime Jepang. Apabila diperhatikan, Jepang sangat berhasil memanfaatkan perkembangan globalisasi sehingga mampu untuk mengenalkan nilai-nilai budaya Jepang kepada dunia. Sebagaimana diketahui bahwa saat ini negara yang dapat memegang globalisasi dapat menjadikan negaranya lebih maju dari sebelumnya. Seperti diungkapkan oleh Setiadi berikut (2007, hlm 1) agar dapat hidup berguna dan bermakna serta mampu mengantisipasi perkembangan masa 
depan, warga negara sangat memerlukan pembekalan ilmu pengetahuan, teknologi, dan seni yang berlandaskan nilai-nilai keagamaan dan budaya bangsa.

Oleh karena itu, Indonesia pun memiliki potensi untuk sedikit mencontoh apa yang dilakukan Jepang terhadap sumber nilainya. Sehingga nilai kebudayaan Indonesia yang begitu banyak dapat dikemas menjadi produk yang dapat dibelajarkan sekaligus menjadi produk entertainmen. Ada dampak positif dari berkembangnya globalisasi terhadap nasionalisme seperti dampak adanya globalisasi dalam sektor sosial budaya, kita bisa mengambil pola pikir atau cara-cara yang baik seperti memelihara disiplin dan etos kerja yang tinggi serta perkembangan IPTEK yang dapat diaplikasikan untuk kemajuan bangsa.

\section{Anime sebagai sumber belajar PKn}

Pendidikan kewarganegaraan merupakan suatu mata pelajaran yang terfokus pada pembentukan diri siswa dari segi agama, budaya, bahasa, usia dan suku bangsa yang berbeda sehingga mampu menjadi warga negara yang baik, cerdas, berkarakter dan terampil. Oleh karena itu, dalam pembelajaran pendidikan kewarganegaraan sebaiknya mengedepankan nilai-nilai karakter dan menggunakan metode pembelajaran sekreatif mungkin serta menekankan keterlibatan siswa dalam aktivitas pembelajaran sehingga siswa menjadi lebih berpartisipasi dalam proses pembelajaran dan pada akhirnya membuat siswa termotivasi belajar dan akan menemukan ide maupun gagasan-gagasan baru yang muncul.

Dalam pembelajaran, dikenal istilah M3SE pembelajaran yaitu materi, metode, media, sumber dan juga evaluasi pembelajaran. Sumber pembelajaran kerap menjadi hal yang belum tergali lebih jauh dengan cara memanfaatkan sumber pembelajaran yang inovatif. Dari Association for Education Communication Technology dan Banks dalam Komalasari (2010) dan Majid (2008) maka sumber pembelajaran adalah segala daya yang dapat dimanfaatkan guru dalam rangka kepentingan pembelajaran guna terciptanya efektivitas dan efisiensi dari tujuan pembelajaran. Sumber pembelajaran yaitu segala sesuatu baik itu tempat, lingkungan, benda dan orang yang mempunyai informasi yang dapat dimanfaatkan guru maupun siswa dalam mempelajari materi 
pelajaran, sehingga meningkatkan pemahaman siswa terhadap materi pelajaran tersebut dan dapat belajar secara lebih optimal.

Ditinjau dari tipe atau asal usulnya, Association for Education Communication Technology dan Banks dalam Komalasari (2010) sumber belajar dibedakan menjadi dua sebagai berikut): Sumber belajar yang dirancang (learning resources by design) yaitu semua sumber yang dibuat oleh guru atau orang yang membuat untuk tujuan pembelajaran. Sumber belajar seperti ini sering dinamakan dengan istilah bahan pembelajaran. Contohnya: buku pelajaran, modul, program, audio, slide suara, transaparansi (OHT). Sumber belajar telah tersedia dan dapat langsung dimanfaatkan (learning resources by utilization) adalah alat yang tidak disengaja dibuat atau dirancang demi keperluan pembelajaran melainkan ditemukan diaplikasi, dan digunakan untuk keperluan pembelajaran. Contohnya: kebun binatang, pejabat pemerintah, surat kabar,film, siaran televisi, sawah. Oleh karena itu, sumber belajar di sekitar kita sangat banyak dan semua itu dapat dimanfaatkan untuk keperluan belajar. Berdasarkan tinjauan tersebut, dapat diketahui bahwa sumber belajar dapat dengan sengaja dibuat sebagai bahan pembelajaran seperti semua sumber pembelajaran yang sengaja dibuat demi tujuan pembelajaran. Selain itu, adapula sumber pembelajaran yang memang tersedia dan hanya dimanfaatkan. Kedua sumber pembelajaran ini sama-sama bermanfaat guna mengoptimalkan kegiatan belajar mengajar.

Oleh karena itu, anime sebagai media digital dapat menjadi alternatif sumber belajar untuk pembelajaran PKn. Dengan segala kemajuan yang dimilikinya, Jepang merupakan negara yang patut dijadikan contoh positif.Terlebih, kesesuaian antara adat ketimuran memberikan kesan bahwa dibanding mencontoh negara-negara Eropa maupun Amerika, mencontoh Jepang menjadi suatu keniscayaan.Dari berbagai hal yang telah diungkapkan, memang dapat dilihat bahwa Jepang memang memiliki hal yang dapat ditiru oleh Indonesia. Bukan meniru secara penuh, melainkan meniru hal yang baik tanpa menghilangkan center of values Indonesia yaitu Pancasila. Menurut Affandi dkk (2015:116): "ada beberapa karakteristik bangsa Jepang yang mendorong 
bangsa ini maju. Pertama, orang Jepang menghargai jasa orang lain. Hal ini dibuktikan dengan "ringannya" mereka dalam mengatakan "arigatou" (terimakasih) ketika mendapat bantuan oranglain dan tidak menganggap remeh jerih payah orang lain meskipun bantuan itu tidak seberapa. Kedua, orang Jepang menghargai hasil pekerjaan oranglain, dilambangkan dengan ucapan otsukaresamadeshita. Ketiga, perlunya setiap orang harus berusaha, dilambangkan dengan ucapan ganbatte kudasai! Keempat, semangat tidak pernah luntur yang dimiliki orang Jepang, sikap tahan banting, dan tidak akan menyerah pada keadaan, atau terkenal dengan semangat bushido. Dari apa yang telah diungkapkan sebelumnya, dapat dilihat bahwa hal-hal yang ada di Jepang sebetulnya di Indonesia juga ada. Namun, Jepang melaksanakannya dengan konsekuen dan konsisten sehingga nilai-nilai tersebut nampak dalam sikap dan perilaku sehari-hari warganegara Jepang. Sebagai contoh, dalam anime Doraemon terdapat tokoh Nobita yang berkarakter pemalas namun selalu jujur, doraemon yang selalu gemar menolong, Giant yang memiliki sifat keras namun ia pekerja keras, Suneo yang sombong namun penurut terhadap orang tuanya. Hal-hal yang tidak jauh dengan aktivitas di keseharian tersebut dapat diterapkan dalam pembelajaran PKn pada materi pengenalan karakter. Selain itu, pada anime Naruto dan banyak anime lainnya yang berkarakter tekad dan usaha yang keras dalam mencapai sesuatu. Hal ini bisa diaplikasikan pada pembelajaran secara umum karena kita terkadang tidak mau bekerja keras jika menginginkan sesuatu. Oleh karena itu, anime yang memiliki nilai-nilai pun dapat dijadikan sebagai sumber belajar disesuaikan dengan nilai-nilai yang selaras dengan nilai di Indonesia. Maka dari itu, guru sebagai fasilitator dapat memfilter nilai baik dan nilai yang kurang sesuai di Indonesia.

\section{KESIMPULAN}

Penggemar anime telah mengenal anime Jepang sejak dini, televisi berperan penting dalam mengenalkan budaya populer anime Jepang kepada warganegara muda Indonesia. Ketertarikan terhadapanime Jepang muncul dalam diri sendiri. Cerita yang dekat dengan keseharian merupakan kekuatan dalam anime Jepang. Anime Jepang 
memiliki ciri khas yang membuatnya unggul dibanding animasi dari negara lain sehingga menarik perhatian warganegara muda Indonesia.

Kekhasan dalam anime Jepang dapat dilihat dari penggambaran tokoh yang sangat mendetail. Tokoh dalam anime Jepang biasanya jika penokohan dibuat cantik maka akan sangat cantik, jika dibuat tampan akan sangat tampan hingga ke tata rambut dan kelopak mata. Selain itu anime Jepang lebih dekat dengan aktivitas normal yang membuatnya berbeda dengan animasi lain. Anime Jepang dapat menjadi alternatif sumber pembelajaran guna memperkaya proses belajar mengajar pada pelajaran Pendidikan Kewarganegaraan. Terdapat kekhasan nilai karakter seperti kerja keras, disiplin, rajin, rendah hati dans sebagainya yang selalu terdapat dalam anime.

Nilai-nilai karakter dalam anime relevan dengan pembelajaran PKn sehingga dapat menjadi alternatif sumber pembelajaran bagi mata pelajaran Pendidikan Kewarganegaraan.Dengan nilai-nilai karakter yang kuat pada anime menjadikan anime selaras dengan Pendidikan Kewarganegaraaan yang juga membelajarkan tentang nilai-nilai karakter. Namun, guru perlu menjadi fasilitator yang juga mampu memfilter anime yang dapat menjadi sumber pembelajaran dalam pembelajaran Pendidikan Kewarganegaraan.

\section{REFERENSI}

Affandi, Idrus. (2015). Memperkokoh Jati Diri Bangsa: Belajar dari Kinerja dan Kultur Bangsa Jepang. Bandung: Mutiara Press

Condry, Ian. (2011). Touching Japanese Popular Culture: From Flows to Contact for Ethnographic Analysis. Publisher: Routledge. Tersedia:http://www.tandfonline.com/loi/cjst20

Erwin, Muhammad. (2010). Pendidikan Kewarganegaraan. Bandung: Refika Aditama

Feriansyah .(2015). Warganegara Digital sebagai Instrumen Warga Negara Global. JPIS Vol. 24 No. 1 Edisi Juni 2015

Hanif, Muhammad. (2011). Studi Media Dan Budaya Populer DalamPerspektif Modernisme Dan Postmodernisme. KOMUNIKA ISSN: 1978-1261. Vol.5 No.2 Juli - Desember 2011 pp.235-251 
Komalasari, K. (2010). Pembelajaran Kontekstual: Konsep dan Aplikasi. Bandung: PT. Refika Aditama.

Kuswarno, Engkus. (2009). Fenomenologi: Konsepsi, Pedoman, dan Contoh Penelitian. Bandung: Widya

Rahmat, dkk.(2013). Pembelajaran Pendidikan Kewarganegaraan (PKn). Bandung: Lab PKn

Majid, A. (2008). Perencanaan Pembelajaran: Mengembangkan Standar Kompetensi Guru. Bandung: PT. Remaja Rosdakarya.

Mark W. MacWilliams.(2008). Japanese Visual Culture. New York: M.E. Sharpe.

Ridaryanthi, Melly. (2014). Bentuk Budaya Populer Dan Konstruksi Perilaku Konsumen, Studi Terhadap Remaja. Jurnal Visi Komunikasi Volume 13, No. 01, Mei 2014: 87-104

Rohani. (2015). Urgensi Pembinaan Tanggung Jawab Warga Negara Melalui Community Civics SOSIAL HORIZON: Jurnal Pendidikan Sosial Vol. 2, No. 2, Desember 2015

Setiadi, E.M. (2007). Pendidikan Pancasila untuk Perguruan Tinggi. Jakarta: PT. Gramedia Pustaka Utama

Venus, Antar \& Helmi, Lucky. (2010). Budaya Populer Jepang di Indonesia: Catatan Studi Fenomenologis Tentang Konsep Diri Anggota Cosplay Party Bandung. Jurnal ASPIKOM volume 1, nomor 1, Juli 2010: 1-24

Vidyarini, Titi Nur. (2008). Budaya Populer Dalam Kemasan Program Televisi. Jurnal Ilmiah SCRIPTURA, Vol. 2, No. 1, Januari 2008: 29 - 37

Wijaya, A. K. (2020). Integrasi Model Role Playing dengan Multimedia terhadap Keterampilan Partisipsi Sosial Siswa. Edueksos : Jurnal Pendidikan Sosial dan Ekonomi. Volume 9 (1). 98-113. DOI: 10.24235/edueksos.v9i1.6420. https://www.syekhnurjati.ac.id/jurnal/index.php/edueksos/article/view/6420

Wing-Fai.Leung.(2014). Idols and celebrity in Japanese media culture, by Patrick W. Galbraith and Jason G. Karlin. Publisher: Routledge. Tersedia: http://www.tandfonline.com/loi/rcel20

Zuriah, Nurul. (2014). "Analisis Teoritik tentang Etnopedagogi Pendidikan Kewarganegaraan sebagai Wahana Pendidikan Budaya dan Karakter Bangsa di Perguruan Tinggi”. SOSIOHUMANIKA: Jurnal Pendidikan Sains Sosial dan Kemanusiaan, Vol.7(2) November, pp.175-188. Bandung, Indonesia: Minda Masagi Press, UNHAS Makassar, and UNIPA Surabaya, ISSN 1979-0112. 